\title{
Understanding of the Information Economics Discipline
}

\author{
Lan LUAN ${ }^{1, a,{ }^{*}}$, Xu-Kun WANG ${ }^{2, b}$ \\ ${ }^{1,2}$ Faculty of Humanities and Social Sciences, Dalian University of Technology, Dalian, 116024, \\ China

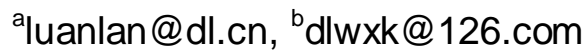

Keywords: Information economics, Origination and development, Structure, Relationship.

\begin{abstract}
Emerging in the years of 60's of 20 century, information economics started to be known in China in the years of 80 s and led to a research upsurge and study trend, with dramatic growing numbers in information economics related documents (like essays and reports). Economic production, social lives and even academic research bear the stamp of information because of its high osmosis, and Information Economics has naturally attracted the researchers from various research areas. After we have analyzed the research backgrounds of information economics researchers, we find that information economics has built up various relationships with many subjects, especially in management, economy and informatics area.
\end{abstract}

\section{The Origination and Development of Information Economics}

The origination of information economics was based on the connection between the needs of society and internal development of western economics. Its origination is not accidental, but a necessity resulted from the growth of western economics.

\section{Information Economics development in foreign countries}

Since its origination in years of 60's of 20 century, Information Economics development has gone through 3 phases: origination and start up phase, scientific structure building phase, stable growth phase.

Origination and start up phase( year of 60's to 70's) focused on the basic theory and actual application, which laid the pavement for the Western Economics theories. There were a serial of essays titled information economics during this phase, including both microeconomics research and macroeconomics research. The important results generated from this phase include the following: Information Economics Measurement Regulation from American economist F. Machlup in 1962, and American economist G. Akerlof's Lemon Market in 1970. In his book, Akerlof mentioned about Un-working Market Theory, and he thought that the information mismatch led to the unworking market. Akerlof argued that the information economics ought to be regarded as a subject.

Scientific structure building phase( 70's to 80's) generated many beneficial results in the area of Macroresearch and Microresearch. The important research results are as following: Information Economics by American Economist Kenneth J. Arrow in 1972, which was regarded as anchor for information economics area. In 1977, American economist M.V.Porat brought about a set of measurement methodology to monitor and measure country information economy level, which was adopted by OECD. During this period, scientific structure building gradually developed and improved. Besides, American economy committee categorized information economics separated from 1976, and first international information economics academic forum was held in 1979. In 1983, International academic journal Information Economics and Policy was firstly published.

Stable growth phase(after 80's) achieved following important research results. In 1983, American Economist P. Hawken published The Next Generation Economy, which defined the information to be key factor for future society and brought about the idea that information economics will be the "next generation economy" instead of current economics. In 1984, American Economist Alan published Information Economics. In his essay, Alen mentioned that Information Economics is economics under uncertain situation, and developed with global information wave. On the one hand, it corrected and improved the traditional economics theory, and on the other hand, 
it pushed the social practical application and macro information economics development. Since 1994, Nobel Economics Awards twice had been granted to economists who had made significant contribution to information economics industry, of whom are J.A.Mirrlees from England and W.Vickrey from America in 1996; G.Akerlof, J.Stiglits and M.Spence from America in 2001. Nobel also three times awarded economists whose contribution were related to information economics, like American J.C.Harsanyi, J.f.Nash and Germany Reinhard Selten in 1994, American R.E.Lucas in 1995 and Iseral R.T.Aumann and American T.Schelling in 2005.

\section{Information Economics Development in China}

Information economics started quite late in China. It is recorded that the term "Information Economics" appeared in China academic periodicals in 1978 for the first time. The first edition of Economics Material Translation published a translated introduction of "Economics Documents Categorization" from American Economics Committee in 1976. We can divide the development of Information Economics in China into two phases, introduction phase and in-depth development phase, and take the foundation of China Information Economics Committee in 1989 as threshold.

Introduction phase(1978-1989): During this period of time, Chinese scholars translated a set of western documents and introduced them into China. For example, The Next Generation Economy by P.Hawken (1983), The Information Economy by M.U. Porat (1987),Economics of Information by K.J.Arrow(1989), etc. Based on the introduction and adaption of western research result, Chinese scholars conducted independent study in this field. There were several books like Information Economics Introduction by Jinde Lin in 1988 and Information Economics Introduction by Weidong Tan in 1988. Generally speaking, domestic results in this period are not profound, which exerts little influence. Nevertheless, academic activities encouraged the development of information economics. Several important activities included the followings: in 1985, Wuhan University listed information economics as formal course into their teaching plan and opened the curriculum of information economics; In December of 1986, First China Information Forum was held in Beijing, and information economics became the main topic of the conference. Between 1987 and 1988, China Economics Information Theory Forum and National Information Economics Forum were held, which later paved the important way for the setup of China Information Economics Committee.

In-depth development phase( 1989-now): During this period, China academic industry generated lot of excellent research results, continuing with absorbing overseas information economics value. Information economics has interacted with China actual situation and is applied to practice profoundly. At the same time, China makes best use of Western information economics theory to analyze the current China economy situation. Here are key activities during this phase: on August 8th, 1989, China Information Economics Committee was founded in Beijing, and Information Economics and Technology was established. At the same time, National Information Economics Forum was held, on which first director and quantitative economist JiaPei Wu raised up the overall framework of China Information Economics Research .On Nov 1st,1992, National Technology Monitoring Bureau issued "People's republic of China National standard: Subject Categorization and Code"(GB/T13745-92), which categorized Information economics as second level subject under first level subject 'Economics' with code 79069.In 1996, Information Economics was listed and introduced in China Applied Economics Specialty listing. National social funding and scientific funding had supported Information Economics research.

In Mar 2009, the author had completed a research in "China Periodicals Content Database" and "China Important Meeting Essay Database", and found that Information Economics as key word first appeared in 1980, and total 2622 pieces of essays with key word of "Information Economics" were published in the period of 1980 - 2009. Thesis quantity with comparative unit per five-year shows increase trend apparently.

1999 is the initial record year for both "China Doctor Thesis Database" and "China Excellent Master Thesis Database". From 1999 to 2008, there are totally 1534 pieces of Master theses and 147 pieces of doctoral dissertations with Information economics as key word in China. 
Scientific evolution history has already proved that mandatory element for a subject to develop in a country is to engage in high education sector and start with university courses. Thus, it can train a capable research team for the evolution of the subject. Information Economics has grown into a popular research industry in China, for its subjects keep close relationship with human resources life.

\section{The structure of Information Economics}

Information Economics is focusing on study of economics with information research as dominant sector. As one of the three elements in objective world, information has the characteristics of objective, dependency and diffusibility. Presently, many subjects have been marked with information, which lead to the complexity and wide breadth of information economics study. With the in-depth study of the research, information economics forms many sub subjects. There are many worldwide reports about information economics structure. Wang Fang sorted it out in details in "Information Economics System Research" (2004). The author also tries to list out the subject structure of it as the flowing five systems, according to the research object and content difference.

The first group composes of several normal subjects like information economics history, micro information economics, macro information economics, information economics metrology and Comparison Information Economics. Normal information economics is the core and basic subject of information economics, and aims to study the common characteristics of information economics questions, for example, information economics connotation and extension, basic content and research method, information cost and efficiency, information resource allocation and management, information measurement and development methodology. Information Economics history describes the history of information economics creation and evolution. Micro information economics studies influence and result of market information brought to economics activities. Micro economics turns down the complete information assumption of classic information economics, so it is also regarded as a new analysis method to economics. Macro Information economics studies information industry and information trading topics in the country and the world, taking information economics as basic research field. Comparison information economics' task is to analyze different historical period, different region, different information economics of social sector and information activities difference. Information economics metrology or metrological information economics make use of mathematics method to analyze information economics and information activities index for better understanding of its regulation.

The second group is called basic information economics, including information economics, information input and output economics, information production economics, information broadcast economics, information service economics, finance information economics and international information economics. This group of subjects is the branch subject of information economics separated from basic information process. For example, International information economics is composed of international information economy and international information trading. The first one emphasizes analysis of world economy informationlization and growing trend, such as analysis on the interaction and influence between information technology and international economy. The latter focuses on the facet of economics issue of information trading, like information industry strategic policy, information services trading and country competitive capability and opening sequence of information service market.

The third group is industrial information economy subjects, including post industry economics, telecommunication economics, publishing economics, broadcasting economics, television economics, advertisement economics and software economics. This group of subjects is edge subjects with focus on the information technology. Due to the transparency of the information technology, more and more traditional industry will be moved into the new research scope.

The forth group is named as information equipment economics, including communication equipment economics, radar manufacture economics, broadcast TV facility economics; electronics components manufacture economics and consumer electronics appliance economics. These subjects 
are formed after the researchers have related economic issue to information economics theory and transformed the methods to information equipment manufacture industry.

The fifth group is edge information economics, including information economics history, information economics philosophy, information economics ethics, Information economics politics, information economics sociology, information economics psychology, information economics management and information technology economics. Those subjects are the interface between information science and philosophy science. Information economics sociology is studying the relationship of information economics and society, like society nature, influencing information economics factor, information economics adjustment, information economics strategy and information economics development interpretation.

\section{The relationship of Information Economics and related subject}

Due to the transparency of information, many sectors of economic production, social life and academic research had been marked with 'Information', which attracted researchers with various backgrounds. While we performed analysis to information economics analyst background, we found close relationship between information economics and other subjects.

In Mar 2009, the author did thorough search in "China Doctor Degree Thesis Database" and "China Excellent Master Degree Thesis Database" with key word of "Information Economics". There are total 118 pieces of master theses and doctoral dissertations after the search. According to the file of "Subject and Major category for Doctor and Master Thesis" released by the State Council in 1997, the author categorizes each thesis. The chart below (table 1) explains clearly the relationship between information economics and other subjects.

Table 1 The Category Sequence of Master Thesis and Doctoral Dissertation Quantity with Key Word "Information Economics"(Year 2000-2007)

\begin{tabular}{|l|c|c|c|c|c|c|c|c|c|}
\hline & $\begin{array}{l}\text { Econo } \\
\text { mics }\end{array}$ & $\begin{array}{l}\text { Manage } \\
\text { ment }\end{array}$ & $\begin{array}{l}\text { Engin } \\
\text { e Science } \\
\text { ering }\end{array}$ & Law & $\begin{array}{l}\text { Agron } \\
\text { o my }\end{array}$ & $\begin{array}{l}\text { Art } \\
\text { s }\end{array}$ & $\begin{array}{l}\text { Philos } \\
\text { o phy }\end{array}$ & $\begin{array}{l}\text { Educa } \\
\text { tion }\end{array}$ \\
\hline $\begin{array}{l}\text { MasterThesi } \\
\text { s quantity } \\
\text { (piece) }\end{array}$ & 48 & 45 & 6 & 3 & 2 & 2 & & 1 & 1 \\
\hline $\begin{array}{l}\text { Doctoral } \\
\text { Dissertation } \\
\text { Quantity } \\
\text { (Piece) }\end{array}$ & 10 & 10 & 2 & & & & & & \\
\hline
\end{tabular}

All the statistics results show that information economics has various relationships with many subjects and groups. Information Economics has special close connection with management and economics. Even though information science is not listed in "Subject and Major category for Doctor and Master Thesis" issued by State Council in 1997, Information Science is still regarded as the important idea origination with the information economics evolution history. The author thinks that Information Economics has the closest relationship with Management, Economics and Information Science.

We can not ignore the relationship between information economics and management. Management is studying human management activity and its application. Management plays important role in information economics application, and information economics can only be transferred to productivity during management process. The transparency of information makes information economics research extended into management study and created opportunities and chances for the related management study as well. Those subjects belonging to the second and the third group branches are the extended results from information economics to management field.

There is no doubt that information economics has close relationship with economics. But there are several sayings about the definition of the relationship. One of the sayings is that information 
economics is a new norm of economics study and it is non-information theory. On one hand, information economics is regarded as extended part of western economics brought to classic economics to improve its theory and application. On the other hand, information economics is a new study norm for economics study, which is called Economics Information Norm. The second saying reveals that information economics is a perspective method of economics, which shows the theory result and knowledge structure. The third saying is that information economics is "application of Asymmetric Information Game Theory in economics"[10]. To summarize, the academic circles regard the relationship between information economics and economics as replacement or the partial to the whole. Such difference results from the different understanding to the term of 'incomplete information', whether it is non-competed information or it is broad scope of complete information. The author thinks that the definition of relationship between information economics and economics can not be separated from the development of information science and society informationlization. With the development of information science and improvement of society information, information economics is regulation change to economics will be strongly supported.

Information science takes information process as study object and analyzes the information and its moving regulation, reaching the goal of exploring human information function and intelligence. Information science provides useful methods for information definition, measurement, transfer, renewals and recognition, and also works as an analysis tool for the information economics. Judging from its name, information economics is the edge subject between information science and economics and must take advantage of information science to develop. In the study of information economics, the main focus is market economic information, also including non economics information like technical information. Basic Information economics belongs to the second group of information economics, and demonstrates the inheritance relationship of information science from information economics.

\section{Reference}

[1] Xiao Yong. 20 years research review of China Information Economics Jingzhou normal education university news (Society Science Publisher)[J],2001(3)

[2] National Philosophy and Society Office Philosophy and society research status and growing trend[M].Beijing: Learning Press 1997.

[3] Wang, Xukun Structure and Position of Creativity subject [J]. HeNan Normal Education University Press 2004,31(6):16-20.

[4] Jing, Jipeng Information Economics[M].Beijing: Tsinghua University Press,2004,p15

[5] Wang, XuKun; Chang, Dongxu Continuous Research of subject scope[J]. HeNan Normal Education University Press 2005,32(6):49-52.

[6] Wu, JiaPei Questions on Information Economics Huaqiao University Press[J],2002(2)

[7] Yao, Kaijian Economics History Beijing: People's republic of China University Press [M], 2003:620.

[8] Guan, Yiping Economics Information Norms Introduction Economy Research[J].1999,(6): 72-79.

[9] Xie, Kang. Overseas information economics study review: Scientific Decision making[J].2000, (4):56-70

[10] Zhang, Weiying. Theory and Information Economics Shanghai: Shanghai People Press[M], 1996.11. 